\title{
IMMUNOLOGICAL ASPECTS OF MULTI-DRUG RESISTANT TUBERCULOSIS EVIDENT IN CHILDREN OF DIFFERENT AGE HAVING BEEN IN CONTACT WITH THE INFECTION
}

\section{Sakhelashvili M. I., Platonova I. L., Sakhelashvili-Bil O. I.}

\section{INTRODUCTION}

Tuberculosis has been a serious medical, biological and social problem in Ukraine and all over the world being caused by the unfavourable ecological situation, unstable social and economic conditions, the increase of risk due to the spread of HIV-infection, population migration and the rising incidence of multi-drug resistant tuberculosis ${ }^{1}$.

Under the deterioration of the tuberculosis epidemiological situation children and teenagers having been in contact with the tuberculosis infection sites and those belonging to social risk groups shall require special attention $^{2}$. Y.I. Feshchenko and the co-author ${ }^{3}$ point to the high incidence of the disease among children and teenagers living in the mycobacterial environment drawing attention to the progress of severe and complicated tuberculosis forms. $45-58 \%$ of the infected children and teenagers were in contact with the tuberculosis infection sites. In most cases multi-drug

${ }^{1}$ Тодоріко Л.Д., Гуменюк М.I., Шевченкою О.С. та ін. Прогностичний аналіз ситуації з туберкульозу у світі за результатами щорічної доповіді ВООЗ. Infusion \& Chemotherapy. 2019. № 4. 10-17. DOI 10.32902/2663-0338-2019-4-10-17.

Фещенко Ю.І., Мельник В.М., Гуменюк М.І., Линник М.І. Епідеміологічна ситуація з туберкульозу в Україні. Infusion \& Chemotherapy. 2019. № 4. 5-9. DOI :10.32902/2663-0338-2019-4-5-9

${ }^{2}$ Абилдаев Т.Ш., Бекембаева Г.С., Кастыкпаева Л.З. Основные факторы риска заболевания в очагах туберкулеза с лекарственной устойчивостью возбудителя. Туберкулез и болезни легких. 2014. № 3. С. 33-35.

Білогорцева О.І. Епідемічна ситуація щодо туберкульозу дітей підліткового віку в Україні. Современная педиатрия. 2016. № 6 (78). 84-87.

Колесник Н.С. Проблеми виявлення, діагностики, лікування і профілактики туберкульозу у дітей з вогнищ туберкульозної інфекції. Запорожский мед. журнал. 2012. № 2. C. $85-89$.

Kuchukhidze G., Kumar AM., Colombani P. et al. Risik factors associate with loss follow-up among multidrug-resistant tuberculosis patients in Georgia/ Public Health Action. 2014. № 4(2). P. 41-46.

${ }^{3}$ Фещенко Ю.І., Мельник В.М., Гуменюк М.І., Линник М.І. Епідеміологічна ситуація з туберкульозу в Україні. Infusion \& Chemotherapy. 2019. № 4. С. 5-9. DOI :10.32902/2663-0338-2019-4-5-9 
resistant tuberculosis is revealed in children and teenagers having been in contact with the tuberculosis infection $\operatorname{site}^{4}$, at that the mass contact with the person discharging bacteria, the late isolation from the mycobacterial environment, non-regular and low quality examination, the lack of an efficient control over the prescribed chemical prophylaxis ${ }^{5}$ are the main causes of the diseases.

According to data provided by the literary sources the occurrence of tuberculosis among children and teenagers is directly linked with the disease occurrence among the adult population as evidenced by the general tendencies of the epidemy and by the direct or indirect link between the disease rate observed in different age categories ${ }^{6}$. Different clinical and organizational aspects of tuberculosis are observed at different age periods of children and teenagers. The lowest disease occurrence is observed at the age of $0-5$ years due to BCG vaccine. The disease occurrence among children at the age of one year is above the average making an exception.

In the context of today, publications that specify immunological disorders as causes that influence the course and effectiveness of multi-drug resistant therapy are still important. Their elimination opens the prospect of improving the effectiveness of antimycobacterial therapy ${ }^{7}$.

4 Актуальні питання щодо хіміорезистентного туберкульозу в Україні / Мельник В.М., Матусевич В.Г., Новожилова І.О. та ін. Укр. пульмонол. журнал. 2017. № 2. С. 52.

Колесник Н.С. Проблеми виявлення, діагностики, лікування і профілактики туберкульозу у дітей з вогнищ туберкульозної інфекції. Запорожский мед. журнал. 2012. № 2. С. 85-89.

5 Актуальні питання щодо хіміорезистентного туберкульозу в Україні / Мельник В.М., Матусевич В.Г., Новожилова І.О. та ін. Укр. пульмонол. журнал. 2017. № 2. С. 52.

Колесник Н.С. Проблеми виявлення, діагностики, лікування і профілактики туберкульозу у дітей з вогнищ туберкульозної інфекції. Запорожский мед. журнал. 2012. № 2. С. 85-89.

${ }^{6}$ Актуальні питання щодо хіміорезистентного туберкульозу в Україні / Мельник В.М., Матусевич В.Г., Новожилова І.О. та ін. Укр. пульмонол. журнал. 2017. № 2. C. 52 .

7 Ільїнська І.Ф., Зубрійчук О.М., Ясир С.Г. Механізми імуносупресії при туберкульозі (аналітичний огляд). Лабораторна діагностика. 2011. № 3(57). С. $47-52$.

Колесник Н.С. Проблеми виявлення, діагностики, лікування і профілактики туберкульозу у дітей з вогнищ туберкульозної інфекції. Запорожский мед. журнал. 2012. № 2. C. 85-89.

Корнева Н.В., Старшинова А.А., Овчинникова Ю.Э. и др. Иммунологические показатели при различной активности туберкулезной инфекции у детей. Медицинская иммунология. 2014. № 5(16). С. 425-430. 
Modern medical sources provide insufficient data about the immune system of children and teenagers depending on the susceptibility of the tuberculosis causative agent strains to antimycobacterial drugs. Consequently, the study of the immunological system of children and teenagers having been in contact with the infection is still of interest.

\section{The system of lymphocytic defence of children diagnosed with pulmonary tuberculosis caused by different susceptibility of the causative agent to antimycobacterial drugs}

27 children (13 children from the observational group and 14 from the treatment group) and 38 teenagers (13 patients from the observational group and 25 from the treatment group) were examined for the purpose of studying the population and subpopulation composition of blood lymphocytes. The observational group consisted of patients diagnosed with tuberculosis caused by TB mycobacterium strains susceptible to antimycobacterial drugs, and the treatment group consisted of patients diagnosed with multidrug-resistant tuberculosis. All the patients have undergone a complex immune testing including the cellular, humoral and specific immunity examination during hospital treatment.

In multidrug-resistant tuberculosis, widespread forms of a specific process (caseous pneumonia, disseminated tuberculosis and generalized tuberculosis with lesions of the lungs and other organs) were revealed in both children and adolescents. The severity of bacterial excretion and the presence of destructive changes in them were 1.3-1.4 times higher than in patients with tuberculosis with preserved sensitivity of MBT strains to antimycobacterial drugs. In family centers of tuberculosis infection, most children and adolescents are ill with chemoresistant form. Among them 1.3 times more often than in patients with no contact, found multi-resistant strains of MBT.

In multidrug-resistant tuberculosis in children 3.2 times more often than in "sensitive tuberculosis", there were signs of progression of a specific process in the form of tuberculosis of peripheral, intrathoracic and mesenteric lymph nodes (lymphogenous dissemination), in teenagers most often in the form of complications of a specific nature. In patients with multidrug-resistant tuberculosis (both in children and adolescents), blood indicators indicated a more pronounced activity of the inflammatory process

\footnotetext{
Черенько, С. О. Імунопатогенез туберкульозу. Астма та алергія. 2013. № 1. C. 32-37.

Starshinova A., Dovgaliuk I., Yakunova O. Immunological parameters in patterns with Tuberculosis. $46^{\text {th }}$ Nordic Lung Congress Reykjavik, Iceland, June 13-15. 2013. 63.
} 
than in tuberculosis, in which the strains of MBT sensitive to antimycobacterial drugs were isolated. In the presence of multidrug-resistant tuberculosis, the intensity of bacterial excretion is greater in both children and adolescents than in "sensitive" tuberculosis.

Severe disorders of the cellular defence were evident in children diagnosed with tuberculosis. At that, the severity of disorders was increasing and was more evident in patients diagnosed with multidrug-resistant tuberculosis

The tendency towards the decrease/increase of some indicators of cellular immunity and its subpopulation composition was more evident in patients diagnosed with "drug susceptible" tuberculosis as compared to healthy people.

The decrease of total lymphocytes $(\mathrm{p}<0.01)$ in the observational group was followed by the decrease of T- lymphocytes CD3+ to $(55.2 \pm 2.6) \%$ with the norm of $(66.5 \pm 3.3) \%, \mathrm{p}<0.05$; T-helper cells showed a tendency to decrease $(\mathrm{CD} 3+\mathrm{CD} 4+)$ to $(31.2 \pm 1.1) \%$ versus $(36.5 \pm 1.8) \%$ for healthy people, $\mathrm{p}>0.05$ and immunoregulatory index decreased correspondingly $\mathrm{CD} 3+\mathrm{CD} 4+/ \mathrm{CD} 3+\mathrm{CD} 8+$ to $1.06 \pm 0.07$ with the norm of $1.32 \pm 0.10$, $\mathrm{p}<0.05$ and the activated natural killer cells $\mathrm{CD} 16 / 56+8+$ increased $(46.8 \pm 2.4 \%$ versus $22.5 \pm 2.3 \%$ for healthy people, $\mathrm{p}<0.001$.

Other tested indicators: Cytotoxic T-lymphocytes CD3+CD56+, activated T-lymphocytes CD3+HLA-DR+, T-suppressor/cytotoxic CD3+CD8+, virgin T-helper cells CD4+45RA+, natural killer cells CD16/56+ were within the norm. It was established that children diagnosed with multidrug-resistant tuberculosis demonstrated the decrease of CD3+ in $37.5 \%$ cases, $\mathrm{CD} 3+\mathrm{CD} 56+$ in $15.4 \%$ cases, $\mathrm{CD} 3+\mathrm{CD} 4+$ in $37.5 \%$ cases, $\mathrm{CD} 3+\mathrm{CD} 4+/ \mathrm{CD} 3+\mathrm{CD} 8+$ in $64.2 \%$ cases, $\mathrm{CD} 4+45 \mathrm{RA}+$ in $47.2 \%$ cases; the increase of $\mathrm{CD} 3+\mathrm{CD} 8+-$ in $33.8 \%, \mathrm{CD} 16 / 56+8+$ in $84.6 \%$ cases (table 1 ).

The more obvious disbalance of the fractional composition of lymphocytic defence having affected the overwhelming majority of the tested indicators was observed in children diagnosed with multidrugresistant tuberculosis. The more severe activation of the suppressorcytotoxic T-cell immunity was evident along with the T-cellular immune deficiency manifested by the decrease of T-lymphocytes CD3+ $(52.8 \pm 2.2) \%$ with the norm of $(66.5 \pm 3.3) \%, \quad \mathrm{p}<0.05$; cytotoxic T-lymphocytes CD3+CD56+ $-(3.9 \pm 0.5) \%$ versus $(5.0 \pm 0.2) \%$ in healthy people, $\mathrm{p}<0.05$; T-helper cells $\mathrm{CD} 3+\mathrm{CD} 4+-(28.5 \pm 1.4) \%$ versus $(36.5 \pm 1.8) \%$ correspondingly, $\mathrm{p}<0.05$; virgin T-helper cells CD4+45RA+ $(49.2 \pm 2.2) \%$ versus $(61.0 \pm 3.1) \%$ in healthy people, $\mathrm{p}<0.05$. The activation was manifested by the increase of suppressor/cytotoxic T-lymphocyte population $\mathrm{CD} 3+\mathrm{CD} 8+$ in $(36.5 \pm 1.1) \%$ cases versus 
$(30.1 \pm 0.9) \%$ in healthy people, $\mathrm{P}<0.05$ and correspondingly by the decrease of immunoregulatory index by 1.8 times $(0.74 \pm 0.08)$ with the norm $(1.32 \pm 0.10), \mathrm{p}<0.0$, and the increase of the peripherally activated natural killer cells CD16/56+8+ $-(56.4 \pm 2.2) \%$ versus $(22.5 \pm 2.3) \%$ for healthy people, $\mathrm{p}<0.05$

Table 1

The population and subpopulation composition of lymphocyte cells of children diagnosed with pulmonary tuberculosis caused by a different susceptibility of the causative agent to antimycobacterial drugs

\begin{tabular}{|l|c|c|c|}
\hline \multirow{2}{*}{\multicolumn{1}{|c|}{ Indicators }} & \multicolumn{3}{c|}{ Examined groups } \\
\cline { 2 - 4 } & $\begin{array}{c}\text { healthy } \\
\text { people } \\
(\mathbf{n = 1 2})\end{array}$ & $\begin{array}{c}\text { Control } \\
\text { group } \\
(\mathbf{n = 1 3})\end{array}$ & $\begin{array}{c}\text { Main } \\
\text { group } \\
(\mathbf{n = 1 2})\end{array}$ \\
\hline Lymphocytes (\%) & $37.7 \pm 1.5$ & $33.8 \pm 1.7 *$ & $32.4 \pm 0.9^{*}$ \\
\hline T-lymphocytes CD3+(\%) & $66.5 \pm 3.3$ & $55.2 \pm 2.6^{*}$ & $52.8 \pm 2.2^{*}$ \\
\hline Cytotoxic T- lymphocytes & $5.0 \pm 0.2$ & $4.8 \pm 0.3$ & $3.9 \pm 0.5^{*}$ \\
\hline $\begin{array}{l}\text { Activated T- lymphocytes } \\
\text { CD3+HLA-DR+(\%) }\end{array}$ & $13.0 \pm 0.8$ & $13.5 \pm 1.2$ & $11.2 \pm 0.7$ \\
\hline $\begin{array}{l}\text { T-helper cells } \\
\text { CD3+CD4+ (\%) }\end{array}$ & $36.5 \pm 1.8$ & $32.7 \pm 1.1$ & $29.5 \pm 1.4^{*}$ \\
\hline T-suppressor/cytotoxic & $30.1 \pm 0.9$ & $31.4 \pm 1.3$ & $36.5 \pm 1.1^{*} \#$ \\
\hline $\begin{array}{l}\text { Correlation of } \\
\text { CD3+CD4+/ CD3+CD8+ }\end{array}$ & $1.32 \pm 0.10$ & $1.08 \pm 0.07 *$ & $0.74 \pm 0.08^{*}$ \\
\hline $\begin{array}{l}\text { Virgin T-helper cells } \\
\text { CD4+45RA+ (\%) }\end{array}$ & $61.0 \pm 3.1$ & $54.7 \pm 1.9$ & $49.2 \pm 2.2^{*}$ \\
\hline $\begin{array}{l}\text { Natural killer cells } \\
\text { CD16/56+ (\%) }\end{array}$ & $14.6 \pm 1.2$ & $15.5 \pm 2.7$ & $14.8 \pm 1.1$ \\
\hline $\begin{array}{l}\text { Activated natural killer } \\
\text { cells }\end{array}$ & $22.5 \pm 2.3$ & $46.8 \pm 2.4 *$ & $56.4 \pm 2.2^{* \#}$ \\
\hline
\end{tabular}

Notes: $1 .{ }^{*}-$ the difference is relevant with regard to healthy people $(\mathrm{p}<0.05-0.001)$; 2 . \#-the difference is relevant with regard to the observational group $(\mathrm{p}<0.05-0.01)$

The comparative analysis of the T-cell immunity subpopulation of children diagnosed with multidrug-resistant tuberculosis and tuberculosis caused by Mycobacterium tuberculosis with the preserved susceptibility of the causative agent to antimycobacterial drugs showed the relevant difference between the groups in terms of $\mathrm{CD} 3+\mathrm{CD} 4+, \mathrm{CD} 3+\mathrm{CD} 8+$, 
$\mathrm{CD} 3+\mathrm{CD} 4+/ \mathrm{CD} 3+\mathrm{CD} 8+$ and $\mathrm{CD} 16 / 56+8+$. The obtained results prove that the cell immunity disorders caused by the loss of dynamic balance between the lymphocytic pools and the regulatory system of cell-cell interactions are more evident in children diagnosed with multidrug-resistant tuberculosis.

The decrease of virgin T-helper cells CD4+45RA+ $(50.3 \pm 2.1) \%$ in the treatment group $(\mathrm{p}<0.05)$ versus $(54.7 \pm 1.9) \%$ in the observational group and $(61,0 \pm 3,1) \%$ in the group of healthy people $(\mathrm{p}>0.05)$ was evident for children diagnosed with pulmonary tuberculosis with a different susceptibility/resistance of the causative agent. The decrease in the amount of CD4+45RA population during an acute inflammation caused by the infection is not the evidence of substantial specific immune disorders and is apparently caused by the migration of cells expressing isoform CD45RA+ to the primary T-cell stimulation site (specific inflammation) with their further differentiation into the effector T-helper cell memory CD4+45RO+.

The study of the quantitative indicators of the activated T-lymphocytes CD3+HLA-DR+ of children diagnosed with pulmonary tuberculosis showed the decrease of HLA-DR-antigen expression on the population of T-lymphocytes in cases of multidrug-resistant tuberculosis. The amount of CD3+HLA-DR+ lymphocytes in children from the treatment group was $(11.2 \pm 0.7) \%$ versus $(13.0 \pm 0.8) \%$ in the group of healthy people, $p>0.05$ versus $(13.5 \pm 1.2) \%$ in patients from the observational group. The decrease of HLA-DR T-lymphocyte surface receptors is a very adverse factor as far as the HLA-DR complex plays the main role in the regulation of all antigenpresenting cells, activation of $\mathrm{T}$-cells, causing the immune response, interaction of macrophages, T-, B-lymphocytes and homeostasis control.

The frequency of the tested indicators deviance observed in children diagnosed with multidrug-resistant tuberculosis was the following: the decrease of $\mathrm{CD} 3+$ in $41.7 \%$ cases, $\mathrm{CD} 3+\mathrm{CD} 56+$ in $33.3 \%$ cases, $\mathrm{CD} 3+\mathrm{CD} 4+$ in $66.7 \%$ cases, $\mathrm{CD} 3+\mathrm{CD} 4+/ \mathrm{CD} 3+\mathrm{CD} 8+$ in $83.3 \%$ cases, CD $4+45 \mathrm{RA}+$ in y $58.3 \%$ cases; the increase of CD3+CD $8+$ in $41.7 \%$ cases, CD16/56+8+ in $91.7 \%$ cases. Taking into consideration the frequency of deviation of some lymphocyte spectrum fractions the following tests were the most informative for the evaluation of the activity of the specific process caused by multidrug-resistant strains of Mycobacterium tuberculosis: $\mathrm{CD} 3+\mathrm{CD} 4+\quad(66.7 \%), \quad \mathrm{CD} 3+\mathrm{CD} 4+/ \mathrm{CD} 3+\mathrm{CD} 8+\quad(83.3 \%), \quad \mathrm{CD} 16 / 56+8+$ $(91.7 \%)$.

Thus, T-lymphocyte deficiency is manifested by the decrease in the spectrum of $\mathrm{CD} 3+, \mathrm{CD} 3+\mathrm{CD} 56+$, mature virgin T-helper cells CD4+45RA+ and the immunoregulatory index followed by the activation of non-specific defence mechanisms - the increase in the population of the activated natural killer cells CD16/56+8+ by 2.5 times as compared to healthy people and by 
1.2 times as compared to the observational group. The excessive activation in the course of the active tuberculosis process, a non-specific cellular defence and the insufficient cellular immune response suppress the development of a specific granuloma serving as a local antimycobacterial isolation barrier. On the other hand, the natural killer cells (NK-cells) specific for the cytokine storm and the lysis of infected cells make a direct destructive effect on the lung tissue. The hyperactive non-specific cellular response complicates the clinical course of the disease creating favourable environment for acute, progressive, destructive and generalized processes [209].

The fractional lymphocytes were studied with the involvement of 38 teenagers diagnosed with sputum smear-positive pulmonary tuberculosis. 13 of them were patients with drug-susceptible tuberculosis (the observational group) and the rest 25 were diagnosed with multidrug-resistant tuberculosis (the treatment group). The studies showed that the lymphocytic defence disorders evident in teenagers diagnosed with tuberculosis practically coincide with the immune disorders (mainly related to lymphocytes as one of the immune system components) observed in children diagnosed with tuberculosis. The decrease in the amount of T-lymphocytes was observed in teenagers diagnosed with tuberculosis irrespective of the drug susceptibility/resistance of the causative agent. The T-lymphocytes population with $\mathrm{CD} 3+$ antigen expression was $(63.4 \pm 2.2) \%$ and $(61.2 \pm 3.1) \%$ in the observational and treatment groups correspondingly versus $(71.5 \pm 2.5) \%$ in the group of healthy people, $\mathrm{p}<0.05$.

The insufficient specific T-lymphocyte response was manifested by the decrease in the amount of cytotoxic T-lymphocytes CD3+CD56+ to $(4.5 \pm 0.3) \%, p>0.05$ and $(4.2 \pm 0.1) \%$ for teenagers from the observational and treatment groups correspondingly, $\mathrm{p}<0.05$, versus $(5.0 \pm 0.2) \%$ for healthy people. The difference was statistically confirmed only for the group of teenagers diagnosed with multidrug-resistant tuberculosis.

The results of the study are stated in table 2 .

The lost of dynamic balance between T-helpers CD3+CD4+ and $\mathrm{T}$-suppressor/cytotoxic lymphocytes $\mathrm{CD} 3+\mathrm{CD} 8+$ with the predominance of cell response mechanisms of suppression was observed in teenagers during the specific process. That was due to the decrease of CD3+CD4+ fraction in the observational and treatment groups to $(33.8 \pm 2.1) \%$ and $(30.4 \pm 1.8) \%$ versus $(41.0 \pm 2.7) \%$ in the group of healthy people, $\mathrm{p}<0.05$ and the increase of $\mathrm{CD} 3+\mathrm{CD} 8+$ to $(29.4 \pm 1.7) \%, \mathrm{p}>0.05$ and $(36.3 \pm 1.5) \%$ versus $(28.5 \pm 1.4) \%$ correspondingly, $\mathrm{p}<0.05$. 
Table 2

The lymphocyte population composition of teenagers diagnosed with pulmonary tuberculosis caused by different susceptibility of the causative agent to antimycobacterial drugs

\begin{tabular}{|l|c|c|c|}
\hline \multirow{2}{*}{ Indicators } & \multicolumn{3}{c|}{ Examined groups } \\
\cline { 2 - 4 } & $\begin{array}{c}\text { healthy } \\
\text { people } \\
(\mathbf{n = 1 5})\end{array}$ & $\begin{array}{c}\text { Control } \\
\text { group } \\
(\mathbf{n = 2 3})\end{array}$ & $\begin{array}{c}\text { Main group } \\
(\mathbf{n}=\mathbf{2 5})\end{array}$ \\
\hline T-lymphocytes CD3+(\%) & $71.5 \pm 2.5$ & $63.4 \pm 2.2^{*}$ & $61.2 \pm 3.1^{*}$ \\
\hline $\begin{array}{l}\text { Cytotoxic T-lymphocytes } \\
\text { CD3+CD56+(\%) }\end{array}$ & $5.0 \pm 0.2$ & $4.5 \pm 0.3$ & $4.2 \pm 0.1^{*}$ \\
\hline $\begin{array}{l}\text { Activated T-lymphocytes } \\
\text { CD3+HLADR+(\%) }\end{array}$ & $11.5 \pm 0.8$ & $11.0 \pm 1.0$ & $10.8 \pm 0.6$ \\
\hline T-helper cells & $41.0 \pm 2.7$ & $33.8 \pm 2.1^{*}$ & $30.4 \pm 1.8^{*}$ \\
\hline $\begin{array}{l}\text { T-suppressor/cytotoxic } \\
\text { CD3+CD8+ (\%) }\end{array}$ & $28.5 \pm 1.4$ & $29.4 \pm 1.7$ & $36.3 \pm 1.5^{* \#}$ \\
\hline $\begin{array}{l}\text { Correlation of CD3+CD4+/ } \\
\text { CD3+CD8+ } \\
\text { (immunoregulatory index } \\
\text { Tx/Tc) }\end{array}$ & $1.30 \pm 0.08$ & $1.15 \pm 0.06$ & $0.84 \pm 0.07^{* \#}$ \\
\hline $\begin{array}{l}\text { Virgin T-helper cells } \\
\text { CD4+45RA+ (\%) }\end{array}$ & $40.5 \pm 2.1$ & $54.3 \pm 2.7^{*}$ & $53.6 \pm 3.2^{*}$ \\
\hline Natural killer cells & $13.5 \pm 1.6$ & $15.4 \pm 1.8$ & $14.9 \pm 1.3$ \\
\hline Activated natural killer cells & $25.8 \pm 2.6$ & $44.0 \pm 3.1 *$ & $47.6 \pm 2.5^{*}$ \\
\hline
\end{tabular}

Notes: *-the difference is relevant with regard to donors $(\mathrm{p}<0.05)$; \#-the difference is relevant with regard to the control group $(\mathrm{p}<0.05)$

The increase in the amount of T-suppressor/cytotoxic lymphocytes CD3+CD8+ was obvious for healthy people and for teenagers diagnosed with multidrug-resistant tuberculosis. The cell response suppression was much more severe in the treatment group as proved by the immuneregulatory index $\mathrm{CD} 3+\mathrm{CD} 4+/ \mathrm{CD} 3+\mathrm{CD} 4+$ being by 1.4 and 1.6 times less as compared to the observational group and the healthy people $(0.84 \pm 0.07)$ versus $(1.15 \pm 0.06), \mathrm{p}<0.05$ and $(1.30 \pm 0.08), \mathrm{P}<0.05$ correspondingly. Consequently, the insufficient specific cell response along with the decrease of $\mathrm{CD} 3+, \mathrm{CD} 3+\mathrm{CD} 56+, \mathrm{CD} 3+\mathrm{CD} 4+$ and the increase of $\mathrm{CD} 3+\mathrm{CD} 4+$ fraction more evident in teenagers diagnosed with multidrug-resistant pulmonary tuberculosis complicate the course of the disease and lead to the specific process chronicity.

The increase of virgin T-helper cells CD4+45RA+ was evident in teenagers diagnosed with pulmonary tuberculosis as opposed to children. 
CD4+45RA+ of patients from the observational and treatment groups increased by 1.3 times as compared to healthy people being equal to $(54.3 \pm 2.7) \%$ and $(53.6 \pm 3.2) \%$ versus $(40.5 \pm 2.1) \%$ correspondingly, $\mathrm{p}<0.05$. On the contrary, children diagnosed with tuberculosis showed the decrease in the amount of virgin T-helper cells CD4+45RA+ being equal to $(50.3 \pm 2.1) \%$ in the treatment group, $\mathrm{p}<0.05 ;(54.7 \pm 1.9) \%$ in the observational group, $\mathrm{p}>0.05$ and $(61.0 \pm 3.1) \%$ in the group of healthy people. The increase of CD4+45RA+ population during the acute phase of inflammation caused by an infection might be the evidence of physiological dynamics disorders of immune responses leading to the specific process chronicity.

The activation of a non-specific cell response was evident in teenagers diagnosed with pulmonary tuberculosis irrespective of the mycobacterium tuberculosis susceptibility/resistance. One should mention that the activation was much more severe in children than in teenagers. The quantity of the activated natural killer cells CD16/56+8+ population increased by 2.1 and 2.5 times in children from the observational and treatment groups as compared to the healthy people, and by 1.7 and 1.8 times in teenagers $(44.0 \pm 3.1) \%$ and $(47.6 \pm 3.2) \%$ versus $(50.4 \pm 1.1) \%$ correspondingly, $\mathrm{p}<0.05$. Consequently, the hyperactive non-specific cell response evident in children and teenagers along with the specific cell immune deficiency caused by the decrease in the population of T-lymphocytes CD3+, cytotoxic CD3+CD56+ T-lymphocytes, activated T-lymphocytes CD3+HLADR+, T-helper cells $\mathrm{CD} 3+\mathrm{CD} 4+$ fail to ensure the complete cell-mediated antimycobacterial defence causing the dissemination of Mycobacterium tuberculosis.

Consequently, the hyperactive non-specific cell response evident in children and teenagers accompanied by the specific cell immune deficiency caused by the decrease of the population of T-lymphocytes CD3+, cytotoxic CD3+CD56+ T-lymphocytes, activated T-lymphocytes CD3+HLADR+, T-helper cells CD3+CD4+ fail to ensure the complete cell-mediated antimycobacterial defence causing the dissemination of Mycobacterium tuberculosis.

The decrease of $\mathrm{CD} 3+$ was revealed in teenagers from the observational group in $52.2 \%$ cases, $\mathrm{CD} 3+\mathrm{CD} 56+$ in $34.8 \%$ cases, $\mathrm{CD} 3+\mathrm{CD} 4+$ in $52.2 \%$ cases, $\mathrm{CD} 3+\mathrm{CD} 4+/ \mathrm{CD} 3+\mathrm{CD} 8+$ in $65.2 \%$ cases, $\mathrm{CD} 4+45 \mathrm{RA}+$ in $43.5 \%$ cases; the increase of $\mathrm{CD} 3+\mathrm{CD} 8+$ was observed in $47.8 \%$ cases, $\mathrm{CD} 16 / 56+8+$ in $78.3 \%$ cases. In patients with pulmonary tuberculosis, regardless of the sensitivity/ resistance of the MBT, activation of a nonspecific cellular response was detected. It should be noted that the 
intensity of this activation was significantly higher in children than in teenagers.

The quantitative parameters of the subpopulation of activated natural killer cells CD16/56+8 + in children of the control and the main group, relative to the healthy, increased 2.1 and 2.5 times, while in the adolescents -1.7 and 1.8 times, respectively and were $(44.0 \pm 3.1) \%$ and $(47.6 \pm 3.2) \%$ relative to $(50.4 \pm 1.1) \%$, respectively, $\mathrm{p}<0.05$.

Hus, non-specialized cellular response, against the background of defective specialized cellular immunity by reducing the population of $\mathrm{CD} 3+$ T-lymphocytes, cytotoxic CD3 + CD56 + T-cells activated CD3+HLADR+ T-lymphocytes, $\mathrm{T}$-helper CD3+CD4+ cells do not provide complete cellular antimycobacterial protection and create conditions for the dissemination of MBT in the body.

The deviance rate of the tested indicators was increasing for teenagers diagnosed with multidrug-resistant tuberculosis and the following was revealed: the decrease in the amount of CD3+ in $56 \%$ cases, CD3+CD56+ in $48 \%$ cases, $\mathrm{CD} 3+\mathrm{CD} 4+$ in $60 \%$ cases, $\mathrm{CD} 3+\mathrm{CD} 4+/ \mathrm{CD} 3+\mathrm{CD} 8+$ in $72 \%$ cases, CD $4+45 \mathrm{RA}+$ in $40 \%$ cases; the increase of CD $3+\mathrm{CD} 8+$ in $64 \%$ cases, CD16/56+8+ in $80 \%$ cases. The following tests were the most informative for the evaluation of the specific process activity caused by multidrugresistant MBT strains: $\mathrm{CD} 3+\mathrm{CD} 4+\quad(60.7 \%), \mathrm{CD} 3+\mathrm{CD} 8+(64.0 \%)$, $\mathrm{CD} 3+\mathrm{CD} 4+/ \mathrm{CD} 3+\mathrm{CD} 8+(72.0 \%), \mathrm{CD} 16 / 56+8+(80.0 \%)$.

The specific inflammatory state observed in children and teenagers was accompanied by the considerable activation of the non-specific cell response with the increase of the fraction of the activated natural killer cells CD16/56+8+.

The non-specific cell response was much more evident in children diagnosed with pulmonary tuberculosis than in teenagers as proved by the increase of $\mathrm{CD} 16 / 56+8+$ by 1.2 times in cases of drug-susceptible tuberculosis and by 2.5 times in cases of multidrug-resistant tuberculosis, whereas the amount of activated natural killer cells increased by 1.7 and 1.8 times in the group of teenagers correspondingly.

A more enhanced activation of the non-specific cell defence with the evident specific cell immune deficiency is observed in children and teenagers diagnosed with multidrug-resistant tuberculosis versus drug susceptible tuberculosis along with the shift of the dynamic balance of lymphocyte populations with the reduction of cytotoxic $\mathrm{CD} 3+\mathrm{CD} 56+$ T-cells, T-helper cells CD3+CD4+ and the decrease of the immunoregulatory index by 1.6 times (children) and 1.5 times (teenagers) (the index is decreased by 1.2 and 1.1 times correspondingly in cases of drug susceptible tuberculosis). 
The excessive activation of the non-specific cell immunity accompanied by the specific cell response deficiency observed in children and teenagers complicate the clinical course of the disease creating favourable conditions for acute, progressive, destructive and generalized processes.

Thus, in children with pulmonary tuberculosis, regardless of the resistance of the pathogen to AMBP, the lack of a specialized cellular response was found: decrease in the $\mathrm{CD} 3$ + cell population; imbalance of fractional T-lymphocyte composition with increasing suppressor / cytotoxic T-lymphocytes CD3 + CD8 +, decrease of immunoregulatory index CD4 + / $\mathrm{CD} 8+$ and activation of non-specialized cellular immunity due to due to the growing population of activated natural killer cells CD16 / $56+8+$.

Multidrug-resistant tuberculosis in children proceeded against the background of pronounced disorders in the system of specialized cellular response with a shift in the dynamic equilibrium between subpopulations of lymphocytic cells toward increasing the number of suppressor / cytotoxic T-lymphocytes CD $3+\mathrm{CD} 4+3$ and +8 cells times immunoregulatory index. In children with "sensitive" tuberculosis IRI decreased 1.2 times.

Specific inflammation in children was accompanied by significant activation of the non-specialized cellular response with an increase in the fraction of activated natural killer cells CD16/56+8+2.1 times in pulmonary tuberculosis with preserved pathogen sensitivity and 2.5 times in multidrugresistant tuberculosis.

The following tests were the most informative for the evaluation of specific process activity caused by multidrug-resistant Mycobacterium tuberculosis strains: $\mathrm{CD} 3+\mathrm{CD} 4+(66.7 \%), \mathrm{CD} 3+\mathrm{CD} 4+/ \mathrm{CD} 3+\mathrm{CD} 8+(83.3 \%), \mathrm{CD} 16 / 56+8+$ $(91.7 \%)$; in teenagers $\mathrm{CD} 3+\mathrm{CD} 4+(60.7 \%), \mathrm{CD} 3+\mathrm{CD} 8+\quad(64.0 \%)$, $\mathrm{CD} 3+\mathrm{CD} 4+/ \mathrm{CD} 3+\mathrm{CD} 8+(72.0 \%), \mathrm{CD} 16 / 56+8+(80.0 \%)$.

\section{B-component of the immune system of children diagnosed with pulmonary tuberculosis with a different susceptibility of the causative agent to antimycobacterial drugs}

B-component of the immune system of children and teenagers diagnosed with pulmonary tuberculosis with a different susceptibility of the causative agent to the antimycobacterial drugs was tested based on the quantity of B-lymphocytes CD19+, immunoglobulins IgA, IgM, IgG and circulating immune complexes (CIC). The test results are stated in Table 3. 25 children (12 from the treatment group and 13 from the observational group) and 38 teenagers ( 25 from the treatment group and 13 from the observational group) were examined.

Along with the normal findings of B-lymphocytes (CD19+) evident in children from the treatment and observational group the apparent enhancement of $\operatorname{IgA}$, IgM, IgG immunoglobulin antibody formation and the 
increase of CIC blood count were observed. In particular, CD19+ of children from the treatment and observational group were $(15.8 \pm 1.7) \%$ and $(16.1 \pm 1.5) \%$ versus $(17.3 \pm 2.0) \%$ in healthy people, $\mathrm{p}>0.05$; IgA $(3.23 \pm 0.13) \mathrm{g} / \mathrm{l}$ and $(2.55 \pm 0.11) \mathrm{g} / \mathrm{l}, \mathrm{p}<0.05$, versus $(1.62 \pm 0.07) \mathrm{g} / \mathrm{l}$ in donors, $\mathrm{p}<0.001 ; \operatorname{IgM}-(2.27 \pm 0.11) \mathrm{g} / \mathrm{l}$ and $(2.52 \pm 0.14) \mathrm{g} / \mathrm{l}, \mathrm{p}<0.05$, versus $(1.05 \pm 0.08) \mathrm{g} / \mathrm{l}$ in donors, $\mathrm{p}<0.001 ; \mathrm{IgG}-(16.8 \pm 1.2) \mathrm{g} / \mathrm{l}$ and $(15.1 \pm 1.5) \mathrm{g} / \mathrm{l}$, versus $(12.8 \pm 1.3) \mathrm{g} / \mathrm{l}$ in healthy people, $\mathrm{p}<0.05$; CIC $(143.7 \pm 8.6)$ opticall density unit and $(122.4 \pm 9.5)$ optical density unit., $\mathrm{p}<0.05$, versus $(78.1 \pm 7.2)$ optical density unit in donors, $\mathrm{p}<0.001$.

Along with the normal findings of B-lymphocytes (CD19+) evident in children from the treatment and observational group the apparent enhancement of $\operatorname{IgA}, \operatorname{IgM}, \operatorname{IgG}$ immunoglobulin antibody formation and the increase of CIC blood count were observed. In particular, CD19+ of children from the treatment and observational group were $(15.8 \pm 1.7) \%$ and $(16.1 \pm 1.5) \%$ versus $(17.3 \pm 2.0) \%$ in healthy people, $\mathrm{p}>0.05$; IgA $(3.23 \pm 0.13) \mathrm{g} / \mathrm{l}$ and $(2.55 \pm 0.11) \mathrm{g} / \mathrm{l}, \mathrm{p}<0.05$, versus $(1.62 \pm 0.07) \mathrm{g} / \mathrm{l}$ in donors, $\mathrm{p}<0.001 ; \operatorname{IgM}-(2.27 \pm 0.11) \mathrm{g} / \mathrm{l}$ and $(2.52 \pm 0.14) \mathrm{g} / \mathrm{l}, \mathrm{p}<0.05$, versus $(1.05 \pm 0.08) \mathrm{g} / \mathrm{l}$ in donors, $\mathrm{p}<0.001 ; \operatorname{IgG}-(16.8 \pm 1.2) \mathrm{g} / \mathrm{l}$ and $(15.1 \pm 1.5) \mathrm{g} / \mathrm{l}$, versus $(12.8 \pm 1.3) \mathrm{g} / \mathrm{l}$ in healthy people, $\mathrm{p}<0.05$; CIC $(143.7 \pm 8.6)$ opticall density unit and $(122.4 \pm 9.5)$ optical density unit., $\mathrm{p}<0.05$, versus $(78.1 \pm 7.2)$ optical density unit in donors, $\mathrm{p}<0.001$.

Table 3

Indicators B - immunity levels in children and adolescents with pulmonary tuberculosis with different sensitivity of the pathogen to antimycobacterial drugs

\begin{tabular}{|c|c|c|c|}
\hline \multirow{2}{*}{ Indicators } & \multicolumn{3}{|c|}{ Examined groups } \\
\hline & healthy people & Control group & Main group \\
\hline Children & $\mathrm{n}=12$ & $\mathrm{n}=13$ & $\mathrm{n}=12$ \\
\hline $\begin{array}{l}\text { B-lymphocytes } \\
\text { CD19+ }(\%)\end{array}$ & $17,3 \pm 2,0$ & $16,1 \pm 1,5$ & $15,8 \pm 1,7$ \\
\hline IgA g/l & $1,62 \pm 0,07$ & $2,55 \pm 0,11^{*}$ & $3,23 \pm 0,13^{* \boldsymbol{\square}}$ \\
\hline $\mathrm{IgM} \mathrm{g} / 1$ & $1,05 \pm 0,08$ & $2,52 \pm 0,14^{*}$ & $2,27 \pm 0,11 *$ \\
\hline $\mathrm{IgG} \mathrm{g/l}$ & $12,8 \pm 1,3$ & $15,1 \pm 1,5$ & $16,8 \pm 1,2 *$ \\
\hline $\begin{array}{l}\text { CIC opticall } \\
\text { density unit. }\end{array}$ & $78,1 \pm 7,2$ & $122,4 \pm 9,5^{*}$ & $143,7 \pm 8,6^{*}$ \\
\hline Teenagers & $\mathrm{n}=15$ & $\mathrm{n}=23$ & $\mathrm{n}=25$ \\
\hline $\begin{array}{l}\text { B-lymphocytes } \\
\text { CD19+ (\%) }\end{array}$ & $14,2 \pm 1,4$ & $20,8 \pm 1,7^{*}$ & $19,2 \pm 1,5^{*}$ \\
\hline IgA g/l & $2,01 \pm 0,09$ & $1,96 \pm 0,09$ & $2,69 \pm 0,26 *$ \\
\hline $\operatorname{IgM~g/l~}$ & $1,27 \pm 0,06$ & $1,81 \pm 0,05^{*}$ & $2,11 \pm 0,14^{* \boldsymbol{\square}}$ \\
\hline $\mathrm{IgG} \mathrm{g/l}$ & $13,5 \pm 1,2$ & $20,5 \pm 1,8^{*}$ & $19,4 \pm 1,3^{*}$ \\
\hline
\end{tabular}




\begin{tabular}{|l|c|c|c|}
\hline $\begin{array}{l}\text { CIC opticall } \\
\text { density unit. }\end{array}$ & $83,4 \pm 5,9$ & $158,4 \pm 8,6^{*}$ & $171,4 \pm 9,2^{*}$ \\
\hline
\end{tabular}

The difference between the treatment and observational groups was statistically confirmed only in terms of IgA having increased by 2 times in children diagnosed with multidrug-resistant tuberculosis versus the healthy people and by 1.6 times in children suffering from tuberculosis with the preserved susceptibility of the causative agent to antimycobacterial drugs. Somewhat different type of B-cell response was observed in teenagers. In accordance with the test results the enhancement of the antibody formation in teenagers diagnosed with pulmonary tuberculosis (the treatment and observational groups) was observed along with the increase of B-lymphocyte population in the treatment and observational groups $(19.2 \pm 1.5) \%$ and $(20.8 \pm 1.7) \%$ versus $(14.2 \pm 1.4) \%$ in healthy people, $\mathrm{p}<0.05$.

IgA, IgM, IgG immunoglobulins and CIC were increasing being a little higher in the treatment group. IgA and IgM were statistically different between the treatment and observational groups of teenagers: $\operatorname{IgA}-$ $(2.69 \pm 0.26) \mathrm{g} / \mathrm{l}$ and $(1.96 \pm 0.09) \mathrm{g} / \mathrm{l}, \mathrm{p}<0.05$, versus $(2.01 \pm 0.09) \mathrm{g} / \mathrm{l}$ in donors, $\mathrm{p}<0.05 ; \operatorname{IgM}-(2.11 \pm 0.14) \mathrm{g} / \mathrm{l}$ and $(1.81 \pm 0.05) \mathrm{g} / \mathrm{l}, \mathrm{p}<0.05$, versus $(1.27 \pm 0.06) \mathrm{g} / \mathrm{l}$ in donors, $\mathrm{p}<0.001$. IgG and CIC were obviously increasing above the norm making no statistical difference.

The frequency of B-component of the immune system activation was somewhat different in teenagers as compared to children. Thus, CD19+ was increased in children from the observational and treatment groups in $23.2 \%$ and $16.7 \%$ cases and in the analogical groups of teenagers it was increased in $52.2 \%$ and $52.0 \%$ cases; $\operatorname{IgA}$ was increased in $69.2 \%$ and $83.3 \%$ of the children diagnosed with susceptible and multidrug-resistant tuberculosis, as well as in $69.6 \%$ and $72.0 \%$ of the examined teenagers. IgM was increased in $61.5 \%$ and $66.7 \%$ of children and in $69.6 \%$ and $72.0 \%$ of teenagers correspondingly; $\mathrm{IgG}$ was increased in $53,8 \%$ and $66.7 \%$ children and in $78.3 \%$ and $76.0 \%$ of teenagers. CIC was increased in $76.9 \%$ and $83.3 \%$ of children and in $82.6 \%$ and $88.0 \%$ of teenagers correspondingly.

Thus, the enhancement of $\operatorname{IgA}$, IgM, IgG antibody formation is revealed in children and teenagers diagnosed with multidrug-resistant tuberculosis and tuberculosis with the preserved susceptibility of the causative agent to antimycobacterial drugs with no evidence of B-lymphocyte population increase; in cases with teenagers the increase of CD19+ is accompanied by the grow of $\operatorname{IgA}$, IgM, IgG blood count.

The following increase of CD19+, IgA, IgM, IgG, CIC was observed in the group of children diagnosed with multidrug-resistant tuberculosis: CD19+ in $16.7 \%$ cases, IgA in $83.3 \%$ cases, $\operatorname{IgM}$ in $66.7 \%$ cases, IgG in 
$66.7 \%$ cases, CIC in $83.3 \%$ cases; the group of teenagers the increase of CD19+ was evident in $52.0 \%$ of the examined patients, the grow of $\operatorname{IgA}$, IgM, IgG and CIC was observed in $72.0 \%, 72.0 \%, 76.0 \%$ and $88.0 \%$ cases correspondingly.

\section{The severity of hypersensitivity reactions to the tuberculin skin test revealed in children diagnosed with drug-susceptible and multidrug-resistant tuberculosis}

The study of hypersensitivity reactions to the tuberculin skin test observed in children and teenagers diagnosed with drug-susceptible and multidrug-resistant tuberculosis was made based on the Mantoux test with 2 TO PPD-L (ТО ППД-Л) and the study results are indicated in Table 4. 64 children (30 from the treatment group and 34 from the observational group) and 151 teenagers ( 76 from the treatment group and 75 from the observational group) were examined.

The comparative analysis of the tuberculin sensitivity severity revealed in children diagnosed with tuberculosis with a different susceptibility of Mycobacterium tuberculosis strains to antimycobacterial drugs showed that the negative and controversial tuberculin skin test results were by 2.8 times more frequent for children suffering from multidrug-resistant tuberculosis as compared to children diagnosed with pulmonary tuberculosis with the preserved susceptibility of the causative agent to antimycobacterial drugs, the frequency of weakly positive tuberculin skin tests was the same in the observational and treatment groups of the examined children. However, severe hypertensive reactions were by 1.3 times more frequent in the treatment group, whereas hyperergic reactions were by 1.3 times less frequent than in children from the observational group. Consequently, the frequency of negative and controversial Mantoux tests with 2 TO PPD-L is higher for children diagnosed with multidrug-resistant tuberculosis with a tendency towards the decrease of hyperergic reactions with 2 TO PPD-L.

The comparative analysis of tuberculin sensitivity conducted for teenagers suffering from tuberculosis showed that the negative and controversial Mantoux tests with 2 TO PPD-L were by 1.8 times more often revealed in cases of multidrug-resistant tuberculosis as compared to drugsusceptible tuberculosis $(14.5 \%$ versus $8.0 \%, \mathrm{p}<0.05)$. The ratio of weakly positive Mantoux tests with 2 TO PPD-L among teenagers from both groups was almost the same. One should mention about the decrease in the frequency of severe and hyperergic tests as compared to the observational group (18.4\% in cases of multidrug-resistant tuberculosis versus $29.3 \%$ in the observational group, $(\mathrm{p}<0.05))$. 
The average diameter of induration in cases of multidrug-resistant tuberculosis was apparently less than in the observational group (10.6 \pm 1.0$)$ $\mathrm{mm}$ versus $(14.2 \pm 0.7) \mathrm{mm} ; \mathrm{p}<0.05)$. The comparison of tuberculin skin sensitivity of children and teenagers diagnosed with multidrug-resistant tuberculosis showed that severe (33.3\%) and hyperergic (33.3\%) Mantoux tests prevailed among children whereas negative and weakly positive tests were revealed in $16.7 \%$ and $20.0 \%$ cases correspondingly. Weakly positive $(38.2 \%)$ and severe $(28.9 \%)$ Mantoux tests with 2 TO PPD-L prevailed among teenagers.

The frequency of severe and hyperergic Mantoux tuberculin skin tests with 2 TO PPD-L points to the diagnostic informative value of the tuberculin skin test for defining the tuberculous activity being equal to $63.3 \%$ and $47.3 \%$ for children diagnosed with multidrug-resistant tuberculous and teenagers correspondingly. However, the negative and controversial tuberculin skin tests did not exclude the active pulmonary tuberculosis in $16.7 \%$ of children and in $14.5 \%$ of teenagers.

The analysis of the tuberculin skin sensitivity of children and teenagers diagnosed with multidrug-resistant tuberculosis depending on the spread of the specific process revealed a tendency towards the increase in the ratio of negative and controversial tests and the apparent decrease of severe and hyperergic tuberculin skin tests evident both in children and teenagers with the spread specific process as compared to patients with the defined changes in the lungs. The severity of tuberculin skin test hypersensitivity reaction evident in children and teenagers diagnosed with active tuberculosis was impacted by the severity of tuberculous intoxication. Concurrently, the apparent increase in the amount of negative and controversial Mantoux tests among patients diagnosed with multidrug-resistant tuberculosis with the evident tuberculous intoxication was revealed as compared to patients with less evident symptoms of tuberculous intoxication (12.3\% versus $1.8 \%$; $\mathrm{p}<0.001)$ which was due to the decrease in the ratio of severe $(8.7 \%$ versus $21.8 \% ; \mathrm{p}<0.001)$ and hyperergic tests $(9.4 \%$ versus $11.6 \% ; \mathrm{p}<0.05)$.

The increase of negative and the decrease of severe and hyperergic tests were revealed in the observational groups of children and teenagers with significant tuberculous intoxication as compared to patients with no evidence of tuberculous intoxication $(20.5 \%$ versus $12.7 \% ; 2.4 \%$ versus $9.1 \% ; \mathrm{p}<0.05$ correspondingly).

Consequently, multidrug-resistant tuberculosis as opposed to drugsusceptible tuberculosis was more often accompanied by negative, controversial or weakly positive reactions to tuberculin. Tuberculous progression caused the apparent increase in the percentage of negative and controversial skin tests. It was established that the specific immune response 
in cases of multidrug-resistant tuberculosis and tuberculosis with the preserved susceptibility of the causative agent to antimycobacterial drugs had "its" unique features. Thus, the moderate increase in the subpopulation of immune specific T-lymphocytes along with their enhanced proliferation was observed in children from the observational group.

The subpopulation of tuberculin-sensitized T-lymphocytes was increased by 1.7 times in children with multidrug-resistant tuberculosis as compared to the observational group $(7.3 \pm 0.4) \%$ versus $(4.4 \pm 0.2) \%, \mathrm{p}<0.001$ and by 5.2 times as compared to the healthy people. One should mention that blast transformative capacity of specific T-lymphocytes during the lymphocyte blast transformation reaction with PPD-L observed in the observational group was apparently less than in children diagnosed with tuberculosis with the preserved susceptibility of the causative agent to antimycobacterial drugs being equal to $(3.5 \pm 0.2) \%$ versus $(4.3 \pm 0.3) \%, \mathrm{p}<0.001$ and $(0.9 \pm 0.2) \%$ in the healthy people, $\mathrm{p}<0.001$.

It was found that for $53.8 \%$ and $50.0 \%$ of children from the observational and treatment groups correspondingly the immune response was adequate and compliant with the active specific process and was evident due to the increased quantity of specific T-lymphocytes and their enhanced capacity. The specific immune disorders were revealed in $47.2 \%$ and $50.0 \%$ of the examined patients correspondingly. In particular, in cases of the active specific inflammation $23.1 \%$ of the examined patients from the observational group and $36.0 \%$ patients from the treatment group showed no evidence (or slight evidence) of the blast transformative capacity of specific T-lymphocytes affected by the increase of tuberculin-sensitized $\mathrm{T}$ lymphocytes. $15.4 \%$ of patients with drug-susceptible tuberculosis and normal I-RUK indicators demonstrated the increased quantity of blast cells transformed by PPD-L. Complete tuberculin anergy was evident in $7.7 \%$ of patients from the observational group and in $16.7 \%$ of children from the treatment group.

Consequently, the appropriate specific immune response with the increase in the population of specific T-lymphocytes and the enhancement of their capacity was observed in $53.8 \%$ of children from the observational group and $50.0 \%$ of the examined patients from the treatment group. The evidence of tuberculin anergy based on the immune specific responses was observed in vitro in $7.7 \%$ of patients with drug-susceptible tuberculosis and in $2(16.7 \%)$ children with multidrug-resistant tuberculosis.

The analysis of quantitative and functional specific immune disorders revealed in teenagers diagnosed with tuberculosis showed that the appropriate specific cell response with the increase of tuberculin-sensitized T-lymphocytes and their proliferation was evident in $62.5 \%$ of teenagers 
from the observational group and $52.0 \%$ of patients from the treatment group. Dysfunctional specific immune disorders were observed in 34.8\% and $48.0 \%$ of the patients correspondingly. In particular, the insufficient (or none) blast transformative activity of specific T-lymphocytes affected by the increased quantity of tuberculin-sensitized T-lymphocytes was observed in $17.4 \%$ and $36.0 \%$ of the examined patients from the observational and treatment groups correspondingly. In $13.0 \%$ and $8.0 \%$ of the patients correspondingly the amount of tuberculin-sensitized T-lymphocytes was within the norm. However, their proliferative capacity was increased under the influence of PPD-L. No specific cell responses to PPD-L were observed in $4.4 \%$ and $12.0 \%$ of patients from the observational and treatment groups correspondingly pointing to the complete tuberculin anergy.

The suppression or the lack of proliferative lymphocyte response to PPD-L might point to the increased readiness of T- lymphocytes to apoptosis or to the antigen cell-membrane conjugations disorders interrupting the interclonal cooperation in the specific cell immune and explaining the tuberculin anergy of T- lymphocytes. Some research papers prove the interrelation between the tuberculin anergy and more severe tuberculous process.

Therefore, the detection of tuberculin energy in immunospecific reactions in vitro may not only predict the unfavorable course of specific inflammation, but also be an early criterion for enhancing antimycobacterial therapy by pathogenic action. In multidrug-resistant tuberculosis, the percentage of people with signs of tuberculin energy increases and is $26.7 \%$ and $17.0 \%$ in adolescents.

Complete immunity testing of patients diagnosed with multidrugresistant tuberculosis improved the diagnostic efficiency and the prediction of the process in children by 1.2 times (from $66.7 \%$ to $83.3 \%$ ) and by 1.3 times in teenagers (from $68.4 \%$ to $91.3 \%$ ). It can serve as the criterion of the specific process activity, its treatment and prediction efficiency.

\section{CONCLUSIONS}

1. Both for children and teenagers pulmonary tuberculosis is accompanied by $\mathrm{T}$-cell immune deficiency manifested by the decrease of total T-lymphocytes CD3+; by the imbalance of the fractional T-lymphocytic composition with the increased quantity of suppressor/cytotoxic T-lymphocytes $\mathrm{CD} 3+\mathrm{CD} 8+$, by the decrease of immunoregulatory index $\mathrm{CD} 4+/ \mathrm{CD} 8+$ and by the activation of the non-specific cell immunity due to the increase of the activated natural killer cells CD16/56+8+ population.

2. The children (irrespective of age) diagnosed with multidrug-resistant tuberculosis showed the evidence of the enhanced activation of the non- 
specific cell immunity with the increase in the fraction of the activated natural killer cells CD16/56+8+ by 2.5 and 1.7 times above the norm for children and teenagers (by 2.1 times and 1.8 in cases of drug-susceptible tuberculosis correspondingly), the insufficient specific cell response with the apparent decrease of $\mathrm{CD} 3+$, cytotoxic T-lymphocytes CD3+CD56+, mature virgin $\mathrm{T}$-helper lymphocytes CD4+45RA+ (the fraction decrease revealed in teenagers $\mathrm{CD} 4+45 \mathrm{RA}+, \mathrm{p}<0.05)$, T-helper cells $\mathrm{CD} 3+\mathrm{CD} 4+$, immunoregulatory index $\mathrm{CD} 4+/ \mathrm{CD} 8+-$ by 1.6 times in children and by 1.5 times in teenagers (in cases of drug-susceptible tuberculosis the immunoregulatory index was decreased by 1.2 and 1.1 times correspondingly), the obvious increase of IgA by 2 times for children, and the increase of $\operatorname{IgA}$ and $\operatorname{IgM}$ for teenagers by 1.3 and 1.7 times correspondingly.

3. CD19+, IgA, IgM, IgG, CIC of children diagnosed with multidrugresistant tuberculosis were increased above the norm being as follows: $\mathrm{CD} 19+$ in $16.7 \%$, IgA in $83.3 \%$, IgM in $66.7 \%$, IgG in $66.7 \%$, CIC in $83.3 \%$; CD19+ was increased in $52.0 \%$ cases in the group of teenagers, $\operatorname{IgA}$ in $72.0 \%$, IgM in $72.0 \%$, IgG in $76.0 \%$, CIC in $88.0 \%$.

4. The specific immune response followed by the considerable increase of tuberculin-sensitized T-lymphocytes was revealed in patients with multidrug-resistant tuberculosis as compared to the healthy people (by 5.2 and 3.0 times in children and teenagers correspondingly) and by the moderate enhancement of their proliferation (by 3.9 and 2.7 times correspondingly); on the contrary, the considerable increase of the specific blast formation (by 4.8 and 3.4 times correspondingly) following the moderate increase of the specific T-lymphocytes population (by 3.1 and 2.1 times in children and teenagers correspondingly) was evident in cases of drug-susceptible tuberculosis. The severe and hyperergic reactions to tuberculin with 2 TO PPD-L were observed in $63.3 \%$ and $47.3 \%$ of children and teenagers correspondingly.

5. The complete immunological examination of patients diagnosed with multidrug-resistant tuberculosis improved the diagnostics efficiency and the process prediction by 1.2 times (from $66.7 \%$ to $83.3 \%$ cases) in children and by 1.3 times (from $68.4 \%$ to $91.3 \%$ ) in teenagers. The defined indicators might serve as the criteria of the specific process activity, its progress and treatment efficiency.

\section{SUMMARY}

To study the population and subpopulation lymphocytic composition of the blood, 27 children (13 children from the control group and 14 from the main group) and 38 adolescents (13 patients from the control group and 
25 from the main group) were examined. The control group included patients with pulmonary tuberculosis caused by antimycobacterial drugs sensitive strains of mycobacterium tuberculosis, the main group - with multidrug-resistant tuberculosis. It has been established that in patients with multidrug-resistant tuberculosis patients there are more pronounced disturbances in cellular immunity, which are associated with the loss of dynamic equilibrium between T-lymphocytes and the regulatory system of intercellular interaction.

\section{REFERENCES}

1. Абилдаев Т.Ш., Бекембаева Г.С., Кастыкпаева Л.З. Основные факторы риска заболевания в очагах туберкулеза с лекарственной устойчивостью возбудителя. Туберкулез и болезни легких. 2014. № 3. C. 33-35.

2. Актуальні питання щодо хіміорезистентного туберкульозу в Україні / Мельник В.М., Матусевич В.Г., Новожилова I.О. та ін. Укр. пульмонол. журнал. 2017. № 2. С. 52.

3. Білогорцева О.І. Епідемічна ситуація щодо туберкульозу дітей підліткового віку в Україні. Современная педиатрия. 2016. № 6 (78). C. $84-87$.

4. Ільїнська І.Ф., Зубрійчук О.М., Ясир С.Г. Механізми імуносупресії при туберкульозі (аналітичний огляд). Лабораторна діагностика. 2011. № 3(57). С. 47-52.

5. Колесник Н.С. Проблеми виявлення, діагностики, лікування i профілактики туберкульозу у дітей з вогнищ туберкульозної інфекції. Запорожский мед. журнал. 2012. № 2. С. 85-89.

6. Корнева Н.В., Старшинова А.А., Овчинникова Ю.Э. и др. Иммунологические показатели при различной активности туберкулезной инфекции у детей. Медицинская иммунология. 2014. № 5(16). C. $425-430$.

7. Тодоріко Л.Д., Гуменюк М.І., Шевченкою О.С. та ін.. Прогностичний аналіз ситуації з туберкульозу у світі за результатами щорічної доповіді ВОО3. Infusion \& Chemotherapy. 2019. № 4. 10-17. DOI:10.32902/2663-0338-2019-4-10-17.

8. Фещенко Ю.І., Мельник В.М., Гуменюк М.I., Линник М.I. Епідеміологіна ситуація 3 туберкульозу в Україні. Infusion \& Chemotherapy. 2019. № 4. C. 5-9. DOI:10.32902/2663-0338-2019-4-5-9.

9. Черенько С.О. Імунопатогенез туберкульозу. Астма та алергія. 2013. № 1. С. 32-37.

10. Яблонский П.К., Довгалюк И.Ф., Старшинова А.А., Якунова О.А. Значение современных иммунологических тестов в диагностике 
туберкулеза у детей. Медищинская иммунология. 2013. № 1(15). C. 37-44.

11. Kuchukhidze G., Kumar AM., Colombani P. et al. Risik factors associate with loss follow-up among multidrug-resistant tuberculosis patients in Georgia/ Public Health Action. 2014. № 4(2). C. 41-46.

12. Starshinova A., Dovgaliuk I., Yakunova O. Immunological parameters in patterns with Tuberculosis. $46^{\text {th }}$ Nordic Lung Congress Reykjavik, Iceland, June 13-15. 2013. 63.

\section{Information about author:} Sakhelashvili M. I., Doctor of Medical Science, Professor, Department of Phthisiology and Pulmonology Danylo Halytskyi Lviv National Medical University 69, Pekarska str., Lviv, 79010, Ukraine

Platonova I. L.,

Ph. D (Medicine), Leading Specialist Danylo Halytskyi Lviv National Medical University 69, Pekarska str., Lviv, 79010, Ukraine

Sakhelashvili-Bil O. I., Postgraduate Student of the Department of Phthisiology and Pulmonology Danylo Halytskyi Lviv National Medical University 69, Pekarska str., Lviv, 79010, Ukraine 